Biografistyka Pedagogiczna

Rok 3 (2018) nr 1

ISSN 2543-6112; e-ISSN 2543-7399

DOI: 10.36578/BP.2018.03.24

Joanna Dominika Belzyt

\title{
Życie każdego z nas jest powieścią
}

[Anne Ancelin Schützenberger, Tajemnice przodków. Ukryty przekaz rodzinny, tłum. Blanka Łyszkowska, Warszawa 2016]

\section{The Life of Each of Us Is a Novel}

Praca Tajemnice przodków. Ukryty przekaz rodzinny stała się we Francji bestsellerem, miała tam do tej pory osiemnaście wydań i weszła do kanonu lektur obowiązkowych na wydziałach psychologii. Na rynku polskim jest jedną z niewielu prac dotyczących systemowej terapii rodzin.

Jej autorka, Anne Ancelin Schutzenberger jest francuską psycholożką i psychoterapeutką pochodzenia rosyjskiego. Urodziła się w Moskwie 29 marca 1919 r. Dorastała w Paryżu, gdzie zdobyła wykształcenie. Była laureatką trzeciej Międzynarodowej Nagrody Soroptimist w 1946 r. W latach 1950-1952 otrzymała stypendium Fullbrighta w dziedzinie psychologii społecznej i dynamiki grupowej. Realizowała je w Michigan w Centrum Badawczym Dynamiki Grup. W 1951 r. odbyła długoterminowy staż w Krajowym Laboratorium Szkoleniowym w Grupach Rozwoju, a w latach 1951-1952 zrealizowała krótkoterminowe staże w Instytucie Moreno (Beacon, Nowy Jork), gdzie pracowała z psychodramą. Ukończyła Americam Trainer and Practitioner. Pracowała jako stażystka, a następnie pracownik naukowy w Centrum Studiów i Badań Psychospołecznych przy francuskim Ministerstwie Pracy (ANIFRMO). Współtworzyła Międzynarodowe Stowarzyszenie Psychoterapii Grupowej (IAGP). Zorganizowała Pierwszy Międzynarodowy

* Joanna Dominika Belzyt - mgr, doktorantka w Instytucie Pedagogiki Katolickiego Uniwersytetu Lubelskiego Jana Pawła II, joannabelzyt@o2.pl. 
Kongres Psychodramy na wydziale lekarskim w Paryżu (1964). W 1967 r. została profesorem na Uniwersytecie w Nicei, gdzie kierowała badaniami w laboratorium psychologii społecznej i klinicznej. W latach 1983-2004 uczestniczyła w nowym La Source Institute (Paryż, Lozanna. Bruksela, Sherbrooke, Quebec), na którym uczyła psychodramy i pracowała jako międzynarodowy trener PET. W późniejszych latach stworzyła z Armelle Thomas Benesse Francuską Szkołę Psychodramy, gdzie rozwijała własną metodę. Zmarła 23 marca 2018 r. Współpracowała m.in. z Jacobem Moreno, Erwinem Goffmannem, Carlem Rogersem, Margaret Mead czy Georgiem Batesonem.

Jest autorką kilkunastu książek o psychodramie, odgrywaniu ról, komunikacji niewerbalnej, nieprzeżytych traumach (np. niedokończonej żałobie). Specyfika publikacji Schutzenberger wynika z ich wielowymiarowości i interdyscyplinarności, autorka sięga do osiągnięć psychologii ogólnej, psychoanalizy, psychologii społecznej, antropologii kulturowej, terapii

1 Anne Ancelin Schützenberger, http://a.ancelin.schutzenberger.pagesperso-orange.fr/, dostęp: 4.05.2018. rodzin i komunikacji niewerbalnej (język ciała, wykorzystanie przestrzeni ${ }^{1}$. Analizowane przez nią zagadnienia ujmowane są w kontekście rodzinnym, historycznym, ekonomicznym, kulturowym, narodowym

i psychohistorycznym. Dotychczas w języku polskim ukazały się dwie pozycje: Tajemnice przodków (2016) oraz Psychogenealogia w praktyce (2017).

2 Genogram - drzewo genealogiczne relacji rodzinnych opatrzone komentarzami, używane w terapii systemowej oraz przez socjologów; A. A. Schutzenberger, Tajemnice przodków. Ukryty przekaz rodzinny, Warszawa 2016, s. 27.

3 Geneosocjogram - wywodzi się z myśli J. L. Moreno, wywodzi się od słów genealogia (drzewo genalogiczne) i socjogram (schemat więzi i relacji), jest to drzewo genealogiczne ukazujące ważne wydarzenia z życia, przedstawione graficzne więzi emocjonalne; tamże, s. 27-28.
Od lat w psychologii badane są przekazy transgeneracyjne i narzędzie, jakim jest genogram ${ }^{2}$. Autorka porusza temat przekazów transgeneracyjnych - przekazywania lęków, nierozwiązanych konfliktów, tajemnic, traum, ukrytych lojalności. Ukazuje, jak powtarzają się w rodzinie śmierci, choroby, wypadki (w szczególności w tych samych datach czy latach życia). Omawia najważniejsze koncepcje badaczy, którzy od czasów Zyggmunta Freuda poruszali temat przekazów międzypokoleniowych, oraz własne przypadki z pracy terapeutycznej, instruuje, jak konstruować geneosocjogram ${ }^{3}$ i na co należy zwracać uwagę, pracując z transgeneracyjnością.

Recenzowana pozycja liczy 296 stron. Składa się z 12 rozdziałów, przedmowy autorki, zakończenia, aneksu i bibliografii. We wstępie autorka omawia zmianę kalen- 
darza i różne rozumienie czasu w kontekście pamiętanych historii. Ostrzega też przed nieumiejętnym stosowaniem psychogenealogii bez odpowiednich kompetencji, omawia prace innych autorów, którzy się tym zajmowali. $\mathrm{Na}$ przykładzie historii „Papugi dziadka” wprowadza czytelnika w temat dziedziczenia.

W pierwszych rozdziałach autorka przedstawia podstawę teoretyczną metody genogramu i geneosocjogramu. Wspomina Zygmunta Freuda (nieświadomość), Carla Gustawa Junga (nieświadomość zbiorowa, synchroniczność i zbieżność dat, przekazy transgeneracyjne), Jacoba Levy Moreno (współświadomość, współświadomość rodzinna) jako tych, którzy wskazali główny tor jej pracy. Opisuje przebytą drogę edukacyjną, główne założenia swojej praktyki i rolę, jaką odegrał w jej życiu zawodowym Jacoba L. Moreno 4 .

Genogram i geneosocjogram jest dla niej narzędziem w diagnozie oraz metodą leczenia. Umiejscawia ich praktyczne wykorzystanie w terapiach rodzin: 1) w grupie Palo Alto, która w warstwie teoretycznej opiera się na dążeniu do równowagi w systemie rodzinnym; 2) w systemo-

4 Jacob L. Moreno (1889-1974) austriacko-amerykański lekarz, psychiatra, socjolog, twórca psychodramy, metody psychologicznej pomocnej w dostosowaniu się jednostki do nowych sytuacji i wydarzeń. wej terapii strategicznej, która wykorzystując teorię podwójnego wiązania, nakierowana jest na rozwiązywanie problemów fizycznych i psychicznych codziennego życia; 3) w systemowej terapii strukturalnej, w której główny nacisk kładzie się na zmianę zwyczajów panujących w relacjach rodzinnych. Geneosocjogram ma najszersze zastosowanie w nurcie psychoanalitycznej terapii rodzin, opartym na podstawach psychoanalitycznych poszerzonych o sieć triad.

W pracy nad transgeneracyjnością autorka zwraca uwagę na koncepcje Ivana Böszörményiego-Nagyego o relacjach w rodzinie. Przekonuje, że przez relacje przodkowie pozostawiają nam w spuściźnie swoje życie, które my z kolei przekazujemy swojemu potomstwu. Według tej koncepcji istnieje „sprawiedliwość rodzinna”, która pozwala zadość uczynić wszelkim niesprawiedliwościom oraz „bilans rachunków rodzinnych”, który ukazuje zyski i straty rodzinne warunkujące pojawiające się w przyszłych pokoleniach problemy. Spowodowane są one często tzw. parentyfikacją, czyli niewłaściwym, odwróconym rozłożeniem zasług i zobowiązań rodzinnych - dziecko od najmłodszych lat wchodzi w rolę rodzica (np. najstarsza córka, która 
przejmuje rolę matki - matka choruje). Duże znaczenie w tworzeniu przekazów mają także tzw. mity rodzinne. Zrozumieć je można, gdy pozna się system wzajemnych zależności rządzących całą rodziną - jawnych i ukrytych zasad funkcjonowania względem siebie jednostek. Uzewnętrzniają się one poprzez wzorce, schematy postępowania i pomagają wyrównywać rachunki rodzinne. Wedle Böszörményiego-Nagyego rodzinna rachunkowość może być zarówno pozytywna (oddawanie miłości, wsparcia, radości, wspólnego świętowania), jak i negatywna (chowane urazy, krzywdy, niesprawiedliwości). Dlatego też w przyszłych pokoleniach powtarzają się te same schematy, chowane urazy niszczą zdrowie, a czasem i życie w przyszłych pokoleniach. Zmiana jest możliwa poprzez zmianę ról komplementarnych (np. pomagający-beneficjent pomocy).

Kolejnym punktem na który zwraca uwagę autorka, są związki reakcji psychologicznych z relacjami, które są warunkowane przez zewnętrzną strukturę zachowań i ukrytą strukturę zobowiązań (np. powtarzające się w rodzinie choroby, zaburzenia). Badaczka opisuje sposób i przypadki wychodzenia z zaburzeń na tym polu. Przekonuje, że duże znaczenie ma przepracowanie lojalności rodzinnych, mitów i historii. Podkreśla wagę radzenia sobie z tzw. drapieżnymi prezentami, które obdarowany jest w stanie spłacić tylko poprzez wieczną wdzięczność, przekazywaną często na przyszłe pokolenia. Aby uzyskać zmianę, należy uzdrowić relacyjność w danej rodzinie. Można tego dokonać poprzez stworzenie mapy synchronicznych wydarzeń rodzinnych (genogram, geneosocjogram), która pozwoli na reinterpretację historii rodzinnej i jej zmianę na wszystkich poziomach: intrapsychicznym, interpersonalnym i egzystencjalnym. Autorka ukazuje często spotykane zasady rodzinne generujące problemy (np. komplementarność, znaczenie najstarszego/najmłodszego dziecka, syna lub córki czy zasada równości). Zachęca do stworzenia własnego geneosocjogramu w celu lepszego zrozumienia tematu. Swoje podejście opisuje jako komplementarne w trzech wymiarach: ciało-czas-przestrzeń, podkreśla wagę aspektu społeczno-ekonomicznego (tzw. neurozy klasowej). Aby w pełni żyć własnym życiem trzeba pokonać „zobowiązanie” wierności przodkom, uświadomienie sobie jej, zrozumienie i transformacja.

Podpierając się teorią Nicolasa Abraham i Marii Török, Schützenberger ukazuje zaburzenia wywołane przez skrywane hańby - niesprawiedliwości, które ujawniają się w przyszłych pokoleniach, pieczołowicie przechowywane 
w rodzinach poprzez mechanizm introjekcji ${ }^{5} \mathrm{i}$ inkorporacji ${ }^{6}$ „widma" i „krypty" ${ }^{8}$. Generować one mogą libido, wybór zawodu czy hobby. Ujawniają się w postaci dziwnych zachowań, chorób, dewiacji. Autorka zwraca uwagę, jak poprzez użycie konceptu par excellence genealogicznego jednostki dualnej możliwe jest odkrycie „krypty” i zamanifestowanie „widma”, co prowadzi do uwolnienia się od niego.

Anne Ancelin podaje też przykłady dzieł artystycznych, z których można wyczytać historie pochodzenia ich twórców, dat śmierci, które powtarzają się (syndrom rocznicy), chorób, które są przekazywane z pokolenia na pokolenie w rodzinie. Ukazuje, jak koszmar i traumy wojenne niesione są jeszcze przez trzy pokolenia. Stwierdza, iż powinno się odkryć prawdę, nawet tę trudną, tragiczną i wstydliwą. To, co ukrywane, uwidacznia się w komunikacji niewerbalnej, w przyszłych pokoleniach, powoduje poważne i długotrwałe traumy. Wysnuwa hipotezę odnoszącą się do lojalności zapisanych w „wielkiej księdze rachunków" rodzinnych, rasowych i kulturowych. Niesprawiedliwości, które stały się tematem tabu, są przyczyną wojen, ludobójstwa i wszelkich konfliktów zbrojnych. Ich ślady odnajdujemy w historii, powieściach, baśniach, mitach czy legendach danego kraju.
5 Introjekcja - mechanizm, który pojawia się w celu obrony ego przed uświadomieniem sobie tego, czego nie akceptujemy. Inkorporacja - proces, w wyniku którego chory wchłania i zachowuje w swoim ciele jakiś przedmiot w sposób mniej lub bardziej fantazmatyczny.

7 Widmo - duch człowieka, który poniósł śmierć w niedający się przyjąć sposób, okrył się hańbą lub doświadczył traumatycznej sytuacji w rodzinie. Nie wolno o nim mówić. Manifestuje się on u któregoś członka rodziny poprzez niewytłumaczalne zachowania, ktoś „nie jest sobą”.

8 Krypta - miejsce między podświadomością dynamiczną a "Ja" introjekcyjnym, tzw. sztuczna podświadomość w samym sercu ,ja", któremu przypada rola strażnika grobu kogoś z rodziny.

Autorka obszernie opisuje swoją drogę pracy z przekazami transgeneracyjnymi. Przytacza historie ze swojego życia i badań naukowych, które ukształtowały jej podejście, m.in. dotyczące syndromu rocznicy, uprzedzeń rasowych i kulturowych, rodzinnych tajemnic. Na jej praktykę mieli wpływ m.in. Margaret Mead, Gregory Bateson, Jürgen Ruesch. Ukształtowana przez nią metoda opiera się głównie na współpracy klienta (w Rogerowskim rozumieniu tego słowa) ze „specjalistą od psyche” (psychologiem, psychoanalitykiem, psychiatrą). Autorka używa drzewa genealogicznego opracowanego przez Tomasa Holmesa i Richarda Rahe ${ }^{9}$, które poszerza o zdarzenia związane z utratą obiektu miłości oraz synchroniczne

9 Jest to kwestionariusz 43 wydarzeń życiowych, znany pod nazwą Social Readjustment Rating Scale (SRRS), który został opracowany przez psychiatrów z Uniwersytetu z Seattle - Tomasa Holmesa i Richarda Rahe, zajmujących się koncepcją stresu i stresora. 
i diachroniczne zbieżności dat i wiek poszczególnych członków rodziny. Zwraca też uwagę na kontekst historyczny, artystyczny, społeczno-ekonomiczny, polityczny i kulturalny ważny dla danego przypadku. Najważniejsze dla niej jest Rogerowskie "nastawienie na osobę" i słuchanie „trzecim uchem”.

Autorka w rozdziale ósmym dokładnie opisuje narzędzie, jakim jest geneosocjogram, sposób jego konstruowania, opisu i interpretacji. Jest to drzewo genealogiczne tworzone z pamięci - ważna jest subiektywna pamięć badanego. Ta reprezentacja graficzna pozwala uwidocznić widma, powtórzenia, synchronie, znaczące zbiegi okoliczności i syndromy rocznicy. Dzięki dokładnemu opisowi i licznym przykładom z praktyki autorki łatwiejsze staje się zrozumienie tego skomplikowanego narzędzia oraz zastosowanie go w praktyce.

Według Schützenberger, kolejnym elementem wpływającym na naszą historię jest imię i nazwisko, które nosimy. Generuje ono sposób postrzegania nas przez innych. Zdaniem autorki, zadając pytanie: „Jak się nazywasz?”, zakładamy, iż dowiemy się, z kogo się ktoś urodził, z jakiej kultury i tradycji, klasy pochodzi. Jakiej jest płci, rasy i wyznania? Od tego, jak się nazywamy, zależy, jakie etykietki zostaną nam społecznie przyklejone. Ważne dla czytelnika mogą być opisane przykłady trudności filiacji związane, np. z: brakiem lub przedwczesną śmiercią ojca, zmianą nazwiska rodowego, byciem dzieckiem z nieprawego łoża, porzuconym czy wydziedziczonym. W związku z tym badaczka podaje, iż trafniejszym pytaniem o pochodzenie mogłoby być "Jak Cię nazywają?". Nazwisko oznacza przynależność do grupy, imię natomiast jest jedną z podstaw tożsamości jednostki. Podkreśla tradycję i znaczenie dla kogoś z rodziny (by przywołać znaczącą osobę dla tego, kto je nadaje). Może być ono zakodowane, zamaskowane lub ukryte w „krypcie”, w zależności, która rodzina ma mocniejszy przekaz. Jako szczególny przykład tego, o czym chce się zapomnieć, są dzieci pozamałżeńskie. Nieprzepracowane traumy przechodzą na następne pokolenia i w nich się ujawniają. Praca z geneosocjogram umożliwia „opowiedzenie swojego życia”, prześledzenie historii rodziny. Autorka twierdzi, iż dostajemy przekazy od przodków w spadku, pozytywne i negatywne „prezenty”. Wysuwa ona postulat, aby genogram był traktowany jako narzędzie instytucjonalne używane w przemyśle, szpitalach i szkołach (u dzieci powyżej dziesiątego roku życia) oraz jako narzędzie samopoznania.

Bazując na psychodramie Moreno, autorka opisuje zalety pracy grupowej z przekazami transgeneracyjnymi. Analizuje przykłady, jak pracując z kil- 
koma osobami, można przyspieszyć proces poznania i wzmocnić zmianę. Doświadczenia jednych uruchamiają wspomnienia innych. Nawet podczas krótkich sesji osoby pochodzące z różnych środowisk otwierają się przed sobą i okazuje się, iż podobne historie zdarzają się w różnych rodzinach. Uczula, iż w odniesieniu do doświadczenia traumatyzującego, wstydliwych faktów, które zostaną przemilczane przez dorosłych, dzieci będą je czuły. „Niewypowiedziane" stanie się tematem tabu dla dzieci tych dzieci. Ukazanie tych traum rodzinnych jest pierwszym krokiem do zmiany. Jak pisze autorka: „Życie każdego z nas jest powieścią", To, co było, jest już napisane, to, co będzie, zależy od nas, jak ją napiszemy.

Praca z grupą, psychodrama może być bardzo pomocna przy odnajdywaniu tożsamości i dziedzictwa kulturowego. Na przykład dzieci porzucone, wychowane w sierocińcach, na ulicy, ale także przez nieobecnych, samotnych rodziców, różnych "wujków" $i$ „tatusiów" mogą mieć problemy z określeniem się w życiu. Wsparcie grupy ułatwia odkrycie i odnalezienie swojego miejsca w rodzie. Jednakże, jak wskazuje badaczka, „odcięcie pępowiny”, uniezależnienie się i obranie własnej tożsamości pojawia się u każdego z nas niemal od narodzin. Dojrzewanie, wyjście z domu rozpoczyna rozwój, wzrost, spełnienie, wejście w dorosłość i odbywa się przez całe życie.

W pracy autorka ukazuje, czym jest prawda zawarta w genach, w jaki sposób ona funkcjonuje. Ilustruje ją przykładami z własnej praktyki klinicznej. Ukazuje powtarzalność chorób, lojalności rodzinne, syndrom rocznicy, kazirodztwo genealogiczne, wielokrotne spowinowacenie, rodziny patchworkowe, związki i dzieci zastępcze, dzieci naprawiające, dziedziczenie struktury rodzinnej, skutki przepowiedni i klątw, konfliktami habitusu ${ }^{10}$. Autorka wysnuwa hipotezę, że kiedy w rodzinie wydarza się coś poważnego i o tym się nie mówi, to „tak jakby z pokolenia na pokolenie przekazywane było coś, o czym nie wolno zapomnieć. Nie może to być wymazane z pamięci, ale nie wolno jednocześnie o tym mówić, można to jedynie przekazać dalej". Nierozstrzygnięte jednak pozostają pytania, dlaczego dana sytuacja przytrafiła się tej a nie innej osobie lub wszystkim. Jedynie a posteriori możemy przewidzieć, które z dzieci weźmie na siebie ukrytą lojalność rodzinną.

Najbardziej powszechnym i znanym narzędziem do pracy z trangeneracyjnością jest genogram. Autorka dokonuje jego transformacji. Nadaje mu kontekst

10 Habitus - właściwe dla danej osoby schematy działania, myślenia oraz jej nieświadome oczekiwania mające rutynowy charakter. 
psychospołeczny i psychoanalityczny oraz obserwację mowy niewerbalnej badanego. Tworzy swoje własne narzędzie - geneosocjogram. Odwołuje się tu do Freuda, który w poczuciu budzącej trwogę niesamowitości upatrywał drogę do ukrytych ich znaczeń. Szczególnie widoczne to jest przy tzw. niesprawiedliwościach losu, np. tych, którzy byli świadkami tragedii, zbrodni, katastrofy i przeżyli. Wiąże się to z poczuciem winy tego, któremu się powiodło. Obserwujemy to u potomków żołnierzy, którzy przeżyli wojnę. Nieujawnione traumy wracają w postaci koszmarów sennych, ataków kaszlu, astmy i innych. Obawiają się też bierną agresją i postawą „ofiary". Terapeutka zapewnia, iż poprzez ujawnienie traumy, zwerbalizowanie, umieszczenie w kontekście rodzinnym i historycznym często objawy zmniejszają się lub ustępują.

W pracy z osobami chorymi na raka autorka, w oparciu o badania Ivána Guerrini (profesora teorii chaosu na uniwersytecie w São Paulo w Brazyli) i Benoit B. Mandelbrot, porównuje namnażanie się komórek rakowych

11 A. A. Schützenberger, Tajemnice przodków, s. 230. do koncepcji fraktali i nieskończonej powtarzalności ${ }^{11}$, które powtarzają się w nieskończoność. Pod wpływem przeciążeń, szkodliwych, traumatycznych przeżyć organizm ulega rozregulowaniu - zaczynają namnażać się komórki chorobowe. Teoria chaosu pozwala zrozumieć, jak z pozoru mało istotne zdarzenie może zmienić wszystko (np. efekt motyla). Dzięki odkodowaniu traumy i ciężkich przeżyć w pracy z transgeneracyjnością możliwe jest ustąpienie i zanik choroby.

Kolejnym istotnym problemem, który w swojej praktyce napotkała autorka, to dzieci wychowywane bez opieki rodziców, matki, ojca lub przez ulicę. Niekiedy ludzie znajdują zastępczych dawców ciepła. Gdy to nie nastąpi, pojawiają się problemy. Dziecko, które nie dostało w dzieciństwie miłości, wsparcia, może nawet umrzeć. Może też przeciwnie poradzić sobie w każdej sytuacji, odnieść sukces bez względu na przeciwności losu (w psychologii fenomen ten został nazwany terminem „niezłomność). U potomków tych dzieci problem ujawnia się i przekazany jest w postaci o wiele większej traumy, osamotnienia, „niezłomności”. Jak wskazują przytoczone w książce badania, nawet czterokrotnie silniejszej ${ }^{12}$.

Schützenberger utrzymuje, iż istnieją dwa rodzaje przekazów transgeneracyjnych: jawne i ukryte. Pierwsze są pomyślane i wypowiedziane przez dziadków, rodziców, dzieci. Są to: zwyczaje rodzinne, talenty, sposób 
życia, zawód przekazywany czy „ręka do roślin”, „dryg do gotowania”, „dobry słuch muzyczny". Ukrytymi przekazami nazywamy to, o czym się nie mówi, zataja, ukrywa, boi się nawet pomyśleć. Nieprzepracowane przechodzą one z pokolenia na pokolenie, zapisują się w ciele i psychice. Potomkowie osób, które przetrwały obozy koncentracyjne, ludobójstwa, masakry wojenne, na przestrzeni kilku pokoleń mają objawy fizyczne, tj. problemy górnych dróg oddechowych, choroby danych organów czy części ciała. Znikają one często, gdy się je wypowie, wypłacze, wykrzyczy, przebaczy. Podobnie dzieje się z takim intensywnym przeżyciem, jakim jest kazirodztwo i gwałt. W przyszłych pokoleniach ujawniają się one w postaci chronicznych zaparć, otyłości, wypadków, lęków (przed ciemnością, mężczyzną, zamkniętymi pomieszczeniami itp.). Badaczka utrzymuję, iż danie możliwości wypowiedzenia, narysowania, odegrania scen utajonych traum, symbolicznie przerywa, zamyka je, zakańcza żałobę, dopełniając niewypowiedziany ból.

W zakończeniu badaczka ukazuje wartość badania własnej historii, jako tej, która buduje tożsamość, opisuje rolę terapeuty w odkrywaniu tajemnic i zamykaniu niedokończonych spraw. Badania genealogiczne i psychogenealogiczne nad własną rodziną porównuje do baldachimu, jaki las tropikalny tworzy dla ziemi - daje życie i umożliwia wzrost. Stwierdza, iż jeszcze przed narodzeniem dziecko dostaje komunikaty, które odczytuje lub stara się zignorować. Za życia rodzina i otoczenie wgrywa mu program - staje się ono częścią kontekstu rodzinnego, wypowiedzianego i niewypowiedzianego. Choć proces ten do końca jeszcze nie został odkryty, to badania naukowe przytoczone przez autorkę udowadniają istnienie syndromu rocznicy, synchronizacji dat narodzin i śmieci, powtórzeń rodzinnych. Jak to ujął Freud, wszystko ma jedno źródło - postęp i rozwój: „Gdyby procesy psychiczne jednego pokolenia nie trwały w pokoleniu następnym, gdyby każdy miał zdobywać swą postawę wobec życia na nowo, wówczas nie było by postępu w tej dziedzinie i prawie żadnego rozwoju". Punktem wyjścia jednostki jest jej genealogia. Jej natura dla nauki nadal pozostaje tajemnicą. Możliwość jej zrozumienia Schützenberger upatruje w rozwoju badań interdyscyplinarnych, których przykłady w ciekawy sposób opisuje. Swoje hipotezy umiejscawia w polu poszukiwań psychoanalizy. Odnosi się do koncepcji projekcji, inkorporacji, wyparcia i rozszczepienia. Opierając się na badaniach i własnej praktyce klinicznej, wysnuwa przypuszczenie, iż dziecko już w łonie matki 
dostaje przekaz do trzech pokoleń wstecz. Stąd tak ważna jest dla niej praca nad genealogią i jej zrozumienie.

W recenzowanej przeze mnie publikacji badaczka porusza tematy kontrowersyjne tyczące się dziedziczenia, czasami trudne i bolące. Próbuje odpowiedzieć na pytania odnoszące się do niezbadanych do tej pory form przekazywania z pokolenia na pokolenie chorób, wypadków, powtarzalności losów, dat narodzin i śmierci. Umiejscawia dokładnie i szeroko opisuje własne miejsce w świecie nauki. Omawia konstrukcje własnego narzędzia badawczego - geneosocjogramu. Swoje teorie popiera przykładami z praktyki klinicznej. W ciekawy sposób łączy interdyscyplinarną naukę i praktykę, co sprawia, iż pozycję czyta się lekko i ze zrozumieniem. Odwołania do sztuki, literatury i kultury umożliwiają spojrzenie na problemy w szerszym kontekście psychospołecznym.

Pozycję tą polecam każdemu, kto interesuje się psychologią, genealogią, historią czy biografią. Pozwala ona spojrzeć na własną i innych historię z większym zrozumieniem, akceptacją wydarzeń, a nawet wybaczeniem. 